\title{
Analyzing the Competency of Principals Using the Framework of the Wales National Standard for Head Teacher in Boosting Teacher's Innovative Behavior
}

\author{
Mukhlis Catio* \\ Universitas Pamulang Tangerang, Banten Province, Indonesia
}

*Corresponding Author: Mukhlis Catio, Universitas Pamulang Tangerang, Banten Province, Indonesia

\begin{abstract}
This study investigated the competency of secondary school principals in specific management areas based on several elements in competency namely personal qualities, knowledge, skills and practices. This research is based on the framework of the National Standards for Principal in the United Kingdom. The survey was conducted by distributing questionnaires to the respondents which consisted of 100 teachers. Also, 5 interviews were carried out to confirm quantitative findings of the study as well as to explain practices and actions taken in each management areas. Descriptive statistics were employed in analyzing quantitative data, whereas qualitative data were manually examined. Results indicated that the school principals were rated as highly competent in all areas. Outcomes of qualitative data analysis also support the findings of quantitative data. However, the study revealed that principal needs support from internal as well as external school community to improve the school performance.
\end{abstract}

Keywords: Principals, Personal Qualities, Innovative Behavior, School teachers

\section{INTRODUCTION}

Management and leadership are the main factors that determine the success of an organization (Harafi and Rajiani, 2013). In a school setting, the opinion expressed indicates that the principal should have the necessary competence to be able to act excellently in managing and leading the school.

The Indonesia Ministry of Education has set some strategies to ensure that schools are managed and led by competent principals. Among them are by appointing principals based on seniority and conducting management and leadership courses from time to time. This activity aims at expanding capacity of the school, enhancing the concept learning organization, focusing on the aspects of personal quality, strengthening the monitoring process and evaluation of educational programs, and ensuring the achievement of Indonesian Education Quality Standards as well as providing guidelines for principals to act excellently in all management and leadership practices at school. With this policy, principals today should already have possessed the necessary competence. However, dissatisfaction with the management and administration of the school was still included in the mass media. There are times when criticisms are thrown open (Kusumawardhani et al., 2017). Research findings of Gunawan (2017) reported that in some situations principals appear to be less proactive, less creative, less innovative, often lost focus, and often lose focus on actual management goals because they are too frequent and confronted with similar problems. Sofo et al. (2012) reported that principals were less open to change and being passive especially in dealing with management problems through the routine. Principals are also said to have difficulties in matters relating to the planning of activities so that there is no time to follow the plans provided. Issues and problems associated with this principals' competence triggered the idea of conducting this study. Since Malaysian education is better compared to Indonesia (Postlethwaite, \& Thomas 2014) as the commonwealth country adopting United Kingdom standard (Alias et al., 2010), this study analyzes Indonesian teachers by using the same framework of professional values or personal qualities required to be useful in school. Among the personal qualities are creative, innovative, motivated, committed, fair, responsible, integrity, willing to bear the risk, caring, concerned, tolerant, sensitive to the needs of students and teachers, is open, confident, dynamic, and respecting others. Since Indonesia and Malaysia have the same cultural proximity (Rajiani et al., 2017), the writer believes that the concept applies to Indonesian when a headmaster would like to promote innovative behavior among teachers. 


\section{LITERATURE REVIEW}

The literature will highlight variables affected the performance of principals in the area of personal qualities, knowledge, skills, and practices in managing teachers to be innovative together with the dimensions forming these variables.

\subsection{Teachers' Innovative Behavior}

In digital societies where competition is extreme, innovation is considered vital for the sustainability and success of organizations. Since the change in organizations depends on people's behavior, innovative employee behavior is fundamental to organizational success and survival. Innovative behavior was described by Baskaran, \& Rajarathinam (2018) as a process in which new ideas are generated, created, developed, applied, promoted, realized, and modified by employees to perform. There are three central reasons why innovative teacher behavior in schools is necessary. First, innovative behavior is imperative to keep up to date with a rapidly changing society. Second, future new technologies and new insights into teaching require innovative behavior. Third, schools should set a good example and act as a starting point for more innovative behavior of our citizens so that society can stay competitive (Thurlings et al., 2015).In other words, teacher innovative behavior is highly essential for the further development of educational professions as well as school organizations and our growth as a knowledge society. Therefore, innovative behavior should be central to the teaching profession. Moreover, to enhance teacher creative practice, it is imperative to identify the role of the headmaster.

\subsection{Principals' Competence}

In Indonesia, there has been a tendency to follow Western approaches to leadership development and training, even though it is recognized that the cultural setting is very contradictive (Sumintono et al., 2015). Due to the cultural similarity, the Malaysian model is this research. The Malaysian Headmaster Standards Competency Model or Standard Kompetensi Kepengetuaan Sekolah Malaysia (SKKSM) enacted in 2006 states that managers and school leaders will be able to appreciate and master the management competence standards when they are in possession of knowledge, professional values, and do best practices in nine management areas in the school namely in management and organizational leadership, curriculum management, co-curriculum management, student affairs management, financial management, office administration management, environmental management and physical facilities, human resource management and development, and external relations management (IAB, KPM 2006). SKKSM can be used to control the behavior and practices of school managers to be more effective, to help school managers to play a role and to better carry out responsibilities, to be the basis of instrument preparation by any party responsible for detecting strengths and weaknesses in school management, as well as guidance in the planning, preparation, and revision of training programs for school managers and school managerial candidates (Abdul Razak 2006). In short, SKKSM is to improve the professionalism of school managers and to serve as a reference and measure to test the effectiveness of management and leadership. The National Standard Principal of Wales is used as a benchmark as it has undergone a rigorous formulation process (Cattell 2004). The National Standard Principal of Wales is reviewed by the Welsh Assembly Government and Headteachers Qualification (Wales): Regulations and Guidance. A consultative review of multiple parties takes into account similar revisions to the National Standards Principal by the National College for School Leadership (NCSL) in England and the revision of the Leadership Standard in Scotland. The parties involved in the consultation were principals of Wales, professional organizations and project board members NPQH. It focuses on three aspects of humanity, namely the primary role of principals, the core attributes of humanity, and the six core areas of humanity. The six core areas of humanity include the areas to determine the direction of the school, to lead teaching and learning, to develop self-esteem and to work with others, to manage organizations, to ensure accountability, and to strengthen relationships with the community (Alias et al., 2010). The National Standard Principal of Wales demonstrates the competence of principals' action (practice) in implementing the roles and responsibilities of a person based on knowledge, skills, quality and personal value, and the professional qualities it possesses. Standards are also based on three fundamental principles of leadership, the principal task that should be centered on learning, focused on direction and oriented orientation. 
Based on the above description, the following hypothesis is formulated:

- Personal quality is positively related to junior high school teacher's innovative behavior.

- Knowledge skill is positively related to junior high school teacher's innovative behavior.

- Management practice is positively related to junior high school teacher's innovative behavior.

- Personal quality, knowledge skill and management practice altogether are positively related to junior high school teacher's innovative behavior.

\section{Methodology}

This study applies a survey method with the correlational approach to examine the relationship between variables tested in the study using three independent variables through data obtained from questionnaires. The independent variable is personal quality, $\left(\mathrm{X}_{1}\right)$, knowledge skill $\left(\mathrm{X}_{2}\right)$, and management practice $\left(\mathrm{X}_{3}\right)$, while the dependent variable is the innovative behavior (Y). The relationship among variables in the study described in Fig.1 below:

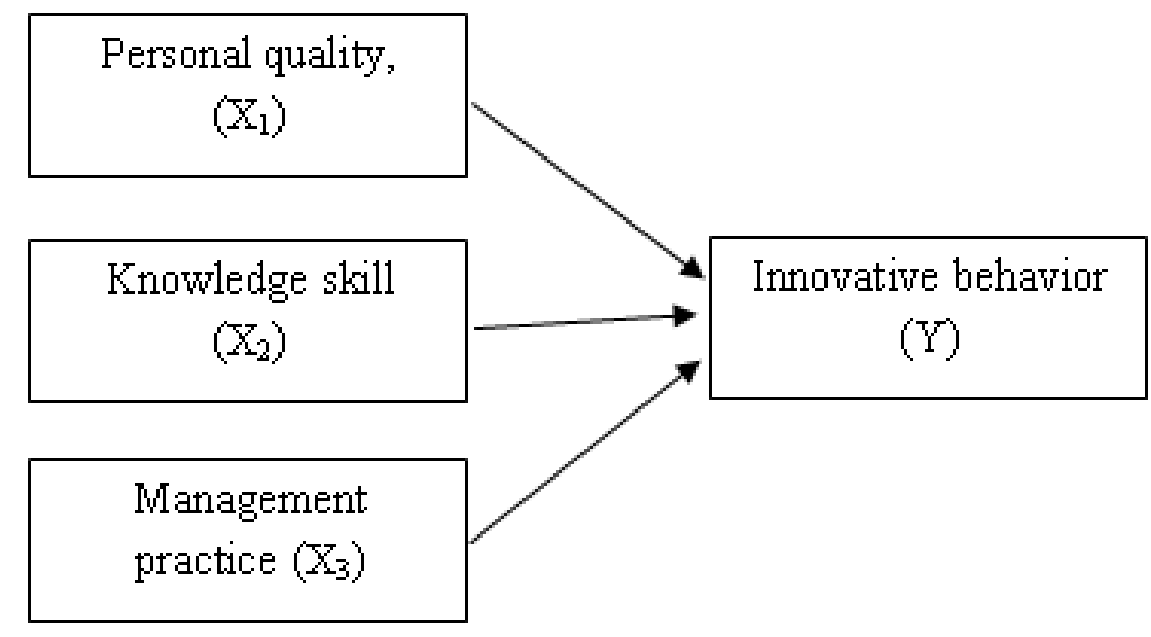

Figure1. Theoretical framework

Teacher's innovative behavior at work was assessed using the Innovative Behavior scale of De Jong and Den Hartog (2005). This scale determines the degree in which the respondent feels he or she behaves innovatively at work. It consists of eight items such as "People I work with think of me as somebody who likes to do new things" and "I enjoy trying new approaches." The construct of personal quality, the construct of knowledge and skill as well as the construct of management practice was adopted work of Alias et al. (2010).

The population of this study is all 118 junior high school teachers in the city of Bekasi, Indonesia where the determination of the sample is conducted by using random sampling with the following formula (Ellen, 2012):

$\mathrm{n}=\mathrm{N} /\left(1+\mathrm{N} \cdot \mathrm{d}^{2}\right)$

where:

$\mathrm{n}=$ number of samples

$\mathrm{N}=$ population

$\mathrm{d}=$ precision

The calculation of the sample size with the formula produces the following result:

$\mathrm{n}=118 /\left(1+118(0.05)^{2}\right)=91.11 \sim 91$

This way the sample size for this research is 91 out of 118 total populations. Hypothesis testing is performed by using a regression analysis to determine the effect of one or more independent variables on the dependent variable. The linearity assumption is conducted before the further test to determine eligibility. Hypothesis testing is conducted at a significance level of 0.05 . 


\section{RESUlT AND DisCUSSION}

The teachers of listed schools were asked to take part in the survey by stating their opinions for four different measures in personal quality, knowledge skill, management practice, and innovative behavior. The linearity test is calculated with $F$-test. Data is linear since upon the calculation the value of each variable is above the critical value for F-test.

\subsection{Personal Quality and Teachers' Innovative Behavior}

To test if data from personal quality and teachers' innovative behavior are linear, F-test has been performed. Since the F value as depicted in table 1 is higher than the critical value of $F$ table, we can continue to test the alternate hypothesis if the personal quality is positively related to teachers' innovative behavior in junior high schools in Bekasi Indonesia. The strength of association of personal quality $\left(\mathrm{X}_{1}\right)$ to teacher's innovative behavior $(Y)$ is inferred from coefficient correlation $\left(r_{x 1}\right)=0.658$.

Table1. Linearity test and coefficient of correlation of personal quality $\left(X_{I}\right)$ to teacher's innovative behavior $(Y)$

\begin{tabular}{|c|c|c|c|c|c|}
\hline Observation & $\mathbf{R}$ & $\mathbf{R}^{2}$ & $\mathbf{F}_{\text {-test }}$ & $\mathbf{F}_{\text {-table }} \alpha$ & \multirow{2}{*}{ Conclusion } \\
\cline { 1 - 3 } & $\mathbf{R}_{\mathbf{x} 1}$ & $\mathbf{r}_{\mathbf{x} 1}^{2}$ & $\mathbf{F}_{\mathbf{x} 1}$ & 0.05 & Significant \\
\hline 91 & 0.658 & 0.432 & 81.62 & 0.42 & \\
\hline
\end{tabular}

$\mathrm{F}_{\text {test }}=81.62$ is above critical value where $\mathrm{F}_{\text {-table }}$ for $(\alpha=0.05)$ is 0.42 indicating that the data is linear and eligible for the next calculation. The coefficient of correlation $\left(r_{x 1}\right)=0.658$ reveals a strong positive relationship between personal quality and teachers' innovative behavior. The coefficient of determination $\left(r^{2} 1\right)=0.432$ denotes that impact of personal quality to teachers' innovative behavior is 43.2 . \% . This is the clear indication that when the headmaster in possession the required personal quality, the teachers' innovative behavior can be encouraged within the organization.

\subsection{Knowledge Skill and Teachers' Innovative Behavior}

To test if data from knowledge skill and teachers' innovative behavior are linear, F-test has been performed. Since the F value as depicted in table 2 is higher than the critical value of $F$ table, we can continue to test the alternate hypothesis if knowledge skill is positively related to teachers' innovative behavior in junior high schools in Bekasi Indonesia. The strength of association of knowledge skill $\left(\mathrm{X}_{2}\right)$ to teacher's innovative behavior $(\mathrm{Y})$ is inferred from coefficient correlation $\left(\mathrm{r}_{\mathrm{x} 1}\right)=0.658$.

Table2. Linearity test and coefficient of correlation of knowledge skill $\left(X_{2}\right)$ to teacher's innovative behavior $(Y)$

\begin{tabular}{|c|c|c|c|c|c|}
\hline Observation & $\mathbf{R}$ & $\mathbf{R}^{\mathbf{2}}$ & $\mathbf{F}_{\text {-test }}$ & $\mathbf{F}_{\text {-table }} \alpha$ & \multirow{2}{*}{ Conclusion } \\
\cline { 1 - 4 } $\mathbf{n}$ & $\mathbf{R}_{\mathbf{x} 2}$ & $\mathrm{r}_{\mathbf{x} 2}^{2}$ & $\mathbf{F}_{\mathbf{x} 2}$ & 0.05 & \\
\hline 91 & 0.431 & 0.185 & 21.50 & 0.42 & Significant \\
\hline
\end{tabular}

The table shows that $F_{\text {test }}=21.50$ is above critical value where $F_{\text {-table }}$ for $(\alpha=0.05)$ is 0.42 indicating that the data is linear and eligible for the next process. The coefficient of correlation $\left(r_{x 2}\right)=0.431$ indicates a moderate positive relationship between knowledge skill and teachers' innovative behavior. The coefficient of determination $\left(r^{2}{ }^{2}\right)=0.185$ indicates that the contribution of knowledge skill to teachers' innovative behavior is $18.5 \%$ while the rest $81.5 \%$ is determined by other factors not included in the model. This small figure may because the leader does not have the style compatible within the respective organization as the appointment is usually based on seniority, not on merit base.

\subsection{Management Practice and Teachers' Innovative Behavior}

Similar to the previous model, to examine if data from management practice and teachers' innovative behavior are linear, F-test has been conducted. The higher $\mathrm{F}$ value as shown in table 3 compared to the critical value of $\mathrm{F}$ table indicates the appropriateness of the model to test the alternate hypothesis if management practice is positively related to teachers' innovative behavior in junior high schools in Bekasi Indonesia. The strength of association of management practice $\left(\mathrm{X}_{3}\right)$ to teacher's innovative behavior $(\mathrm{Y})$ is observable from coefficient correlation $\left(\mathrm{r}_{\mathrm{x} 3}\right)=0.662$.

Table3. Linearity test and coefficient of correlation of management practice $\left(X_{3}\right)$ to teacher's innovative behavior $(Y)$

\begin{tabular}{|c|c|c|c|c|c|}
\hline Observation & $\mathbf{R}$ & $\mathbf{R}^{\mathbf{2}}$ & $\mathbf{F}_{\text {-test }}$ & $\mathbf{F}_{\text {-table }} \alpha$ & \multirow{2}{*}{ Conclusion } \\
\cline { 1 - 3 } $\mathbf{n}$ & $\mathbf{R}_{\mathbf{x} 3}$ & $\mathrm{r}_{\mathbf{3} 3}^{2}$ & $\mathbf{F}_{\mathbf{x} 3}$ & 0.05 & \\
\hline 91 & 0.662 & 0.438 & 23.00 & 0.42 & Significant \\
\hline
\end{tabular}


The table shows that $\mathrm{F}_{\text {test }}=23.00$ is above critical value where $\mathrm{F}_{\text {-table }}$ for $(\alpha=0.05)$ is 0.42 indicating that the data is linear and eligible for the next process. The coefficient of correlation $\left(r_{x 2}\right)=0.662$ indicates a strong positive relationship between work management practice and teacher's innovative behavior. The coefficient of determination $\left(\mathrm{r}_{\times 3}^{2}\right)=0.438$ means that the contribution of management practice to teacher's creative action is $43.8 \%$ while the rest $56.2 \%$ is determined by other factors not included in the model.

\subsection{Personal Quality, Knowledge Skill, and Management Practice to Teachers' Innovative Behavior}

When tested together the model is specified as:

$\hat{Y}=b_{0}+b_{1} X_{1}+b_{2} X_{2}+b_{3} X_{3}$

Where:

$\hat{\mathrm{Y}}=$ Teacher's Innovative Behavior

$\mathrm{b}_{0}=$ constant

$b_{1}, b_{2}, b_{3}=$ regression coeficient

$\mathrm{X}_{1}=$ Personal Quality

$\mathrm{X}_{2}=$ Knowledge Skill

$\mathrm{X}_{3}=$ Management Practice

Table4. Multiple Regression Analysis Summary

\begin{tabular}{|c|c|c|c|c|c|c|}
\hline Model & $\beta$ & $\mathbf{R}$ & $\mathbf{R}^{2}$ & $\mathbf{F}_{\text {-test }}$ & $\mathbf{F}_{\text {-tabel }} \alpha$ & Conclusion \\
\hline & & & & 54.213 & $\begin{array}{l}\mathbf{0 . 0 5} \\
3.95 \\
\end{array}$ & Significant \\
\hline Constant & 20.112 & & & & & \\
\hline Personal Quality & 0.328 & & & & & \\
\hline Knowledge Skill & 0.247 & 0.722 & 0.521 & & & \\
\hline Management Practice & 0.417 & & & & & \\
\hline
\end{tabular}

Tables 4 show the results of multiple regression analysis. The chart shows a significant $\mathrm{F}$ statistic indicating that the model has strong prediction strength $(\mathrm{F}=54.213, \mathrm{p}<0.01)$. As further shown in Table 4, all variables altogether are strongly correlated to teachers' performance as shown by the coefficient of correlation $=0.722$ and also affect teacher's innovative behavior significantly as more than $52 \%$ of the variation in the determination of teachers' performance is explained by the model ( $\mathrm{R}$ Square $=0.521$.

The model derives the following equation: $\hat{\mathrm{Y}}=20.112+0.328 \mathrm{X}_{1}+0.247 \mathrm{X}_{2}+0.417 \mathrm{X}_{3}$.

Observing the value of regression coefficient from the highest to the lowest, this model confirms that management practice $\left(X_{3}\right)$ is the most popular variable in defining the teachers' innovative behavior, followed by personal quality $\left(\mathrm{X}_{1}\right)$ and knowledge skill $\left(\mathrm{X}_{2}\right)$.

Qualitative data findings support quantitative data finding where most principals have certain personal qualities that make them accepted as managers and leaders in the school. The quality of personal qualities available to most principals and implied is a characteristic of responsible personal qualities, being open, caring, loving and kind. While personal traits are rarely mentioned or expressed implicitly, but there is at least one person who stated that principals are visionary, consistent/firm, able to face stress/patience, self-confident, innovative, proactive, respectful of others, committed to duty, cooperative, diligent, sharp-mindedness, integrity, empathy, support / helpful, fair, efficient, flexible, initiative, creative and skill as a problem solver. Possessing cultural proximity to Malaysia, the study supported the previous research of Alias et al (2010) that principals have the personal qualities of insight, accountability, consistency, motivated, able to cope with stress, self-confident, innovative, caring, proactive, caring, empathy, visibility, skill as a problem solver, fair, efficient, tolerant, committed, creative, cooperative, diligent, sharp-minded, integrity, open attitude, friendly, and respectful attitude others at high levels. 


\section{CONCLUSION}

The findings prove that there is a positive and significant relationship between the personal quality on teachers' innovative behavior, knowledge skill on teachers' innovative behavior and management practice on teachers' innovative behavior among teachers working in junior high schools located in Bekasi, Indonesia. Having cultural proximity to Malaysia, the model of Wales National Standard for Head Teacher applied in Malaysia can be used to boost teacher's innovative behavior in Indonesia. However, further research should be extended to the full geographical area to make the result is more generalizable.

\section{REFERENCES}

[1] Alias, B. S., Yussof, A. B. M., Mustapha, R., \& Ibrahim, M. S. (2010). Competency of Malaysian Principals Based on Personal Qualities, Knowledge Skills, and Practices in Managing School. Jurnal Pendidikan Malaysia (Malaysian Journal of Education), 35(2), 31-41.

[2] Al-sharafi, H., \& Rajiani, I. (2013). Leadership Practices and Talent Turnover: Study on Yemeni Organizations. Business and Management Research, 2(3), 60.

[3] Baskaran, K., \& Rajarathinam, M. (2018). Innovative Teaching Practices in Educational Institutions (ITPEI). International Journal of Educational Sciences, 20(1-3), 72-76.

[4] De Jong, J. P. J., \& Den Hartog, D. N. (2005). Determinanten van innovatief gedrag: een onderzoek onder kenniswerkers in het MKB. Gedrag \& Organisatie, 18(5), 235-259.

[5] Ellen, S. (2012). Slovin's formula sampling techniques.

[6] Gunawan, I. (2017). Instructional management in Indonesia: a case study. Researchers World, 8(1), 99.

[7] Institut Aminuddin Baki, Kementerian Pelajaran Malaysia. 2006. Amalan-amalan terbaik pengurusan dan kepimpinan sekolah menengah Malaysia. Genting Highlands: Institut Aminuddin Baki.

[8] Kusumawardhani, A. P., Widiati, U., \& Fachrurrazy, F. (2017). Perception of Senior High School English Teachers and Students about Personal Competence. Jurnal Pendidikan Humaniora, 5(2), 88-98.

[9] Postlethwaite, T. N., \& Thomas, R. M. (Eds.). (2014). Schooling in the ASEAN region: Primary and secondary education in Indonesia, Malaysia, the Philippines, Singapore, and Thailand. Elsevier.

[10] Rajiani, I., Yunus, A. R., Prastyorini, J., \& Kalangi, M. H. E. (2017). THE NEW CARBON ECONOMY IN SOUTHEAST ASIA; INDONESIA \& MALAYSIA FROM CULTURAL PERSPECTIVE. In Economic and Social Development (Book of Proceedings), 20th International Scientific Conference on Economic and Social (p. 147).

[11] Sofo, F., Fitzgerald, R., \& Jawas, U. (2012). Instructional leadership in Indonesian school reform: overcoming the problems to move forward. School Leadership \& Management, 32(5), 503-522.

[12] Sumintono, B., Sheyoputri, E. Y., Jiang, N., Misbach, I. H., \& Jumintono. (2015). Becoming a principal in Indonesia: possibility, pitfalls and potential. Asia Pacific Journal of Education, 35(3), 342-352.

[13] Thurlings, M., Evers, A. T., \& Vermeulen, M. (2015). Toward a model of explaining teachers' innovative behavior: A literature review. Review of Educational Research, 85(3), 430-471.

Citation: Mukhlis Catio. "Analyzing the Competency of Principals Using the Framework of the Wales National Standard for Head Teacher in Boosting Teacher's Innovative Behavior" International Journal of Managerial Studies and Research (IJMSR), vol 7, no. 2, 2019, pp. 1-6. doi: http://dx.doi.org/10.20431/23490349.0702001.

Copyright: (C) 2019 Authors. This is an open-access article distributed under the terms of the Creative Commons Attribution License, which permits unrestricted use, distribution, and reproduction in any medium, provided the original author and source are credited. 